\title{
POLA PENDEKATAN EVALUASI HASIL BELAJAR SISWA DI SEKOLAH
}

\author{
Serlis Rusandi \\ Institut Agama Hindu Negeri Tampung Penyang Palangkaraya \\ bawiayahfda@gmail.com
}

\begin{abstract}
Riwayat Jurnal
Artikel diterima

Artikel direvisi

Artikel disetujui
\end{abstract}

\begin{abstract}
Abstrak
Evaluasi hasil belajar dilakukan untuk memantau proses, relevansi kemajuan belajar siswa dengan tujuan atau standar yang telah ditetapkan, dan perbaikan pengajaran siswa serta kelemahan - kelemahan yang telah dilakukan dalam kegiatan proses belajar mengajar. Menetukan dan menjelaskan apa yang harus dinilai selalu mendapat prioritas dalam proses evaluasi. Efektifitas evaluasi bergantung pada telitinya deskripsi tentang apa yang akan dievaluasi, karena itu agar hasil evaluasi dapat mencerminkan informasi yang akurat tentang hasil belajar siswa dan efektivitas program pengajaran yang telah dilaksanakan, maka diperlukan teknik dan pendekatan analisis evaluasi yang digunakan untuk menentukan keakuratan informasi hasil evaluasi yang telah dilakukan dan merupakan syarat mutlak yang diperlukan untuk menghasilkan keputusan yang tepat dalam memilih alternatif yang terbaik berdasarkan kesesuaian antara hasil yang dicapai dan tujuan yang ingin dicapai.

Pola pendekatan dalam evaluasi harus dipilih sesuai dengan tujuan yang akan dilayaninya dan harus dipertimbangkan apakah teknik evalusi merupakan metode yang paling efektif untuk menetukan apa yang ingin diketahui oleh siswa. Evaluasi yang komprehensif menuntut berbagai teknik evaluasi. Salah satu alasan perlunya berbagai prosedur evaluasi adalah karena setiap jenis hanya menyajikan bukti-bukti yang unik tetapi terbatas tentang perilaku siswa. Untuk mendapatkan gambaran yang komplit tentang pencapaian siswa perlu kombinasi hasil dari berbagai teknik.

Pemakaian pendekatan dalam evaluasi yang sewajarnya menuntut kewaspadaan akan keterbatasannya seperti juga kekuatannya. Semua alat evaluasi selalu mengandung kekurangan tertentu. Pertama, adalah kesalahan sampling, yakni hanya dapat mengukur sampling kecil pada satu waktu. Kesalahan kedua adalah pada alat evaluasi itu sendiri atau proses memakai alat itu. Sumber kesalahan yang lain lahir dari penafsiran yang salah tentang hasil evaluasi, menganggap alat-alat tersebut mengandung presisi yang sebenarnya tidak mereka miliki. Sebaik-sebaiknya alat evaluasi hanya memberikan hasil yang bersifat mendekati saja sehingga harus ditafsirkan secara wajar. Kesadaran atas keterbatasan alat evaluasi memungkinkan penggunaannya lebih efektif, dan kesalahan-kesalahan dalam teknik evaluasi dapat
\end{abstract}


dihilangkan dengan cara hati-hati dalam memilih dan menggunakannya. Evaluasi hanyalah alat mencapai tujuan bukan merupakan tujuan akhir.

Kata kunci : Pola Pendekatan, Evaluasi, Hasil Belajar Siswa.

\section{PENDAHULUAN}

Evaluasi merupakan subsistem yang sangat penting dan dibutuhkan dalam setiap sistem pendidikan, karena kegiatan evaluasi merupakan suatu proses sistematis guna mendapatkan bukti-bukti yang jelas tentang efektifitas dari kegiatan pendidikan dalam bentuk evaluasi hasil belajar siswa. Evaluasi hasil belajar dilakukan untuk memantau proses, relevansi kemajuan belajar siswa dengan tujuan atau standar yang telah ditetapkan, dan perbaikan pengajaran siswa serta kelemahan-kelemahan yang telah dilakukan dalam kegiatan proses belajar mengajar. Hasil evaluasi dipergunakan untuk memberikan arah atau landasan yang kuat dalam menentukan pertimbangan pengambilan keputusan mengenai kebijakan pendidikan.

Agar hasil evaluasi dapat mencerminkan informasi yang akurat tentang hasil belajar siswa dan efektivitas program pengajaran yang telah dilaksanakan, maka diperlukan teknik dan pendekatan analisis evaluasi yang digunakan untuk menentukan keakuratan informasi hasil evaluasi yang telah dilakukan dan merupakan syarat mutlak yang diperlukan untuk menghasilkan keputusan yang tepat dalam memilih alternatif yang terbaik berdasarkan kesesuaian antara hasil yang dicapai dan tujuan yang ingin dicapai.

Salah satu alat evaluasi untuk mengukur hasil belajar adalah menggunakan tes. Tes yang baik dapat memberikan hasil ukur yang cermat dan akurat, sehingga hasil tes mampu menunjukkan perbedaan-perbedaan kecil yang ada pada objek ukurnya. Untuk mendapatkan tes yang baik maka perlu dilakukan analisis terhadap butir tes. Tujuan utama analisis butir tes, yaitu untuk memperoleh informasi objektif tentang butir tes yang digunakan dan untuk mengidentifikasi butir-butir yang kurang baik. Butir-butir tes tersebut mungkin terlalu mudah, sukar, atau tidak dapat membedakan antara siswa yang berkemampuan tinggi dan rendah. Secara 
garis besar ada dua cara menganalisis butir tes, yaitu analisis butir soal secara teoretik/kualitatif dan analisis butir tes secara empiris/kuantitatif. Dengan demikian analisis hasil evaluasi belajar hendaknya dijadikan bahan untuk menyempurnakan program pembelajaran yaitu memperbaiki kelemahan-kelemahan pengajaran dan memberikan bimbingan belajar kepada siswa yang memerlukannya.

\section{PEMBAHASAN}

\subsection{Pengertian Evaluasi dan Evaluasi Hasil Belajar}

Evaluasi adalah proses

memberikan atau menentukan nilai kepada objek tertentu berdasarkan suatu kriteria tertentu (Nana Sudjana, 2004:3). Proses pemberian nilai tersebut berlangsung dalam bentuk interpretasi yang diakhiri dengan judgement. Interpretasi dan judgement merupakan tema penilaian yang mengimplikasikan adanya suatu perbandingan antara kriteria dan kenyataan dalam kontek situasi tertentu. Karena itu, dalam kegiatan evaluasi selalu ada objek/program, ada kriteria dan ada interpretasi/judgement. Sementara itu, Djemari Mardapi (2004:19) menyatakan bahwa evaluasi merupakan salah satu rangkaian kegiatan dalam meningkatkan kualitas, kinerja atau produktivitas suatu lembaga dalam melaksanakan programnya.

Stufflebeam (Worthen \& Sanders, 1973:129) merumuskan pengertian evaluasi sebagai "...the process of delineating, obtaining, and providing useful information for judging decision alternatives". Definisi tersebut kurang lebih artinya bahwa evaluasi sebagai proses menggambarkan, memperoleh dan menyajikan informasi yang berguna untuk menetapkan alternatif-alternatif keputusan. Sesuai dengan pengertian ini maka setiap kegiatan evaluasi atau penilaian merupakan proses yang sengaja direncanakan untuk memperoleh data atau informasi. Berdasarkan data tersebut, maka dijadikan sebagai bahan pertimbangan dalam membuat suatu keputusan.

Fokus evaluasi dalam pendidikan adalah individu, yaitu prestasi belajar yang dicapai kelompok atau kelas. Melalui hasil evaluasi akan diperoleh informasi tentang apa yang telah dicapai dan mana yang belum, dan selanjutnya informasi ini digunakan untuk perbaikan suatu program. Sehubungan dengan kegiatan pengajaran atau pendidikan 
Nana Sudjana (2004:3) menegaskan bahwa evaluasi hasil belajar adalah proses pemberian nilai terhadap hasil-hasil belajar yang dicapai siswa dengan kriteria tertentu. Gronlund \& Linn (1990:5) merumuskan pengertian evaluasi sebagai berikut : "Evaluation as a systematic process of collecting, analyzing, and interpreting information to determine the extent to wich pupils are achieving intructional objectives". Definisi ini sangat berkaitan dengan proses pembelajaran, yaitu sebagai proses yang sistematis untuk menentukan atau membuat keputusan sampai sejauh mana tujuan pembelajaran telah dicapai oleh siswa.

Evaluasi hasil belajar merupakan kegiatan evaluasi yang terjadi dalam pendidikan. Tyler (dalam Fernandes, 1985:1) mendefinisikan evaluasi pendidikan sebagai "the procces of determining to what extent the educational objectives are being realized". Hal ini menegaskan bahwa evaluasi di dalam pendidikan merupakan suatu proses penentuan sejauh mana tujuan pendidikan telah tercapai. Lebih lanjut Ahmann dan Glock (1981:7) mengemukakan bahwa evaluasi pendidikan "... is the systematic process of determining the effectiveness of educational endeavor in the light of evidence". Hal ini menyatakan bahwa evaluasi pendidikan adalah suatu proses sistimatis guna mendapatkan bukti-bukti yang jelas tentang efektifitas dari kegiatan pendidikan.

Dengan demikian, dapat dikatakan bahwa evaluasi bukan sekedar menilai suatu aktivitas secara spontan dan insidental melainkan merupakan kegiatan untuk menilai sejauh mana suatu aktivitas telah tercapai, dengan cara yang terencana, sistematis dan terarah berdasarkan atas tujuan yang jelas, dengan didukung informasi yang akurat sebagai hasil pengukuran untuk mengambil suatu keputusan.

Berdasarkan beberapa pengertian tentang evaluasi yang telah diuraikan di atas dapat dirumuskan bahwa evaluasi pendidikan adalah suatu prosedur sistematis untuk memperoleh informasi tentang pelaksanaan dan tingkat ketercapaian suatu program pendidikan, yang pelaksanaannya dapat dilakukan ketika program sedang berlangsung atau setelah selesainya suatu program dimana hasil informasi yang diperoleh dapat 
digunakan sebagai pijakan dalam perbaikan program.

\subsection{Tujuan dan Prinsip-prinsip Evaluasi Hasil Belajar}

Pada dasarnya untuk mengukur pelaksanaan suatu program dapat diketahui melalui kegiatan evaluasi. Stufflebeam (Worthen \& Sanders, 1981:210) menyatakan bahwa tujuan evaluasi adalah untuk memperoleh informasi guna memilih alternatif yang terbaik. Lebih lanjut dikatakan evaluasi juga bertujuan untuk menentukan kesesuaian antara hasil yang dicapai dan tujuan yang ingin dicapai. Nana Sudjana (2004:4) mengemukakan bahwa tujuan evaluasi hasil belajar adalah untuk :

a. Mendeskripsikan kecakapan belajar para siswa sehingga dapat diketahui kelebihan dan kekurangannya dalam berbagai bidang studi atau mata pelajaran yang ditempuhnya.

b. Mengetahui keberhasilan proses pendidikan dan pengajaran di sekolah, yaitu seberapa jauh keefektifannya dalam mengubah tingkah laku para siswa kearah tujuan pendidikan yang diharapkan.

c. Menentukan tindak lanjut hasil penilaian, yaitu melakukan perbaikan dan penyempurnaan dalam hal program pendidikan dan pengajaran serta strategi pelaksanaannya.

d. Memberikan pertanggungjawaban dari pihak sekolah kepada pihak-pihak yang berkepentingan, yaitu : pemerintah, masyarakat dan para orang tua siswa.

Tujuan evaluasi yang lebih mendasar di dalam kegiatan pembelajaran adalah untuk memberikan informasi yang akurat tentang hasil belajar siswa dan efektivitas program pengajaran yang telah dilaksanakan. Keakuratan informasi hasil evaluasi merupakan syarat mutlak yang diperlukan untuk menghasilkan keputusan yang tepat. Cronbach (Worthen \& Sanders, 1973:44) menyatakan bahwa kegunaan evaluasi dalam pengambilan keputusan dipisahkan atas 3 (tiga) tipe, yaitu :

1) Perbaikan pelajaran, menentukan bahan pengajaran dan metode yang tepat digunakan dan untuk mengetahui dimana letak perubahan yang dibutuhkan.

2) Keputusan terhadap individu-individu, mengenali kebutuhan-kebutuhan murid untuk menyusun perencanaan pengajaran, mempertimbangkan sikap 
siswa dengan maksud untuk seleksi dan pengelompokan, mempelajari kelebihan dan kelemahan yang dimiliki siswa.

3) Pengaturan administrasi, menilai bagaimana sistem, bagaimana individu guru, dan sebagainya.

Ahmann \& Glock (1981:8) menyatakan bahwa evaluasi dalam pendidikan secara khusus mempunyai dua tujuan, yaitu: (1) menolong guru menetapkan tingkatan sampai dimana tujuan pendidikan telah dicapai dan (2) membantu guru-guru untuk mengetahui murid-muridnya sebagai individu. Tujuan yang pertama adalah yang utama, sebagaimana perubahan-perubahan perilaku siswa adalah selalu dievaluasi dalam pengertian tujuan pendidikan. Tujuan kedua adalah melengkapi pada tujuan pertama jika guru-guru diberikan informasi secara menyeluruh mengenai murid-muridnya, mereka akan dapat lebih baik dalam merencanakan pengalaman mereka dan menentukan derajat dimana tujuan pendidikan telah dicapai. Dengan demikian, tujuan evaluasi hasil belajar adalah menentukan efektifitas dan efesiensi kegiatan pembelajaran dengan indikator utama pada keberhasilan atau kegagalan siswa mencapai tujuan pengajaran yang telah ditetapkan, selanjutnya dimanfaatkan bagi perbaikan dan pengembangan sistem pengajaran berikutnya.

Mengingat pentingnya hasil evaluasi belajar dalam mencerminkan kualitas pendidikan, maka di dalam kegiatan perencanaan dan pelaksanaannya harus memperhatikan beberapa prinsipprinsip evaluasi. Hal ini dimaksudkan sebagai petunjuk dalam melakukan kegiatan evaluasi dengan benar dan efektif. Gronlund \& Linn (1990:6-7) memberikan prinsip-prinsip evaluasi secara umum sebagai berikut :

kejelasan dan kepastian tentang apakah prioritas yang dievaluasi, (2) teknik harus sesuai dengan tujuan evaluasi, (3) evaluasi yang komprehensif memerlukan macam-macam bukan tujuan, tetapi alat untuk mencapai tujuan, (4) ketepatan penggunaan teknik evaluasi diperlukan untuk mengetahui keterbatasannya.

Hasil evaluasi belajar hendaknya dijadikan bahan untuk menyempurnakan program pembelajaran yaitu memperbaiki kelemahan - kelemahan pengajaran dan memberikan bimbingan belajar kepada siswa yang memerlukannya. Nana 
Sudjana (2004:8-9) memberikan prinsipprinsip evaluasi hasil belajar sebagai berikut :

a. Dalam evaluasi hasil belajar hendaknya dirancang sedemikian rupa sehingga jelas abilitas yang harus dievaluasi, materi evaluasi, alat evaluasi dan interpretasi hasil evaluasi.

Sebagai patokan atau rambu-rambu dalam merancang evaluasi hasil belajar adalah kurikulum yang berlaku dan buku pelajaran yang digunakannya.

b. Evaluasi hasil belajar hendaknya menjadi bagian integral dari proses belajar mengajar dan evaluasi senantiasa dilaksanakan pada setiap proses belajar mengajar sehingga pelaksanannya berkesinambungan.

c. Agar diperoleh hasil belajar yang objektif dalam pengertian menggambarkan prestasi dan kemampuan siswa sebagaimana adanya. Evaluasi harus menggunakan berbagai alat evaluasi dan sifatnya komprehensif yang mencakup aspek kognitif, afektif dan psikomotor.

d. Evaluasi hasil belajar hendaknya diikuti dengan tindak lanjut. Data hasil evaluasi sangat bermanfaat bagi guru maupun bagi siswa. Hal ini berkaitan dengan kemajuan siswa terutama prestasi dan kemampuan yang di milikinya.

Berdasarkan kedua pendapat tersebut di atas, dapat disimpulkan bahwa prinsip-prinsip evaluasi, yaitu :

evaluasi harus jelas tujuan dan rancangan serta digunakan tepat sesuai tujuannya, (2) evaluasi harus dilakukan secara terarah dan berkesinambungan, (3) evaluasi harus bersifat objektif dan komprehensif, dan (4) evaluasi harus diikuti dengan tindak lanjut.

\subsection{Pola Pendekatan Penilaian dalam Evaluasi Hasil Belajar Siswa}

Keputusan yang diambil sebagai hasil penilaian dalam evaluasi merupakan hal yang sangat penting bagi kepentingan kehidupan dan perkembangan siswa. Untuk itu perlu adanya beberapa prinsip yang diperhatikan dalam melakukan penilaian agar dapat dilaksanakan secara cermat dan dapat dipertanggungjawabkan. Djemari Mardapi (2005:75) menyatakan bahwa dalam prinsip penilaian yang terpenting adalah akurat, ekonomis, dan mendorong peningkatan kualitas pembelajaran. Akurat berarti hasil penilaian mengandung kesalahan sekecil 
mungkin, dan ekonomis berarti sistem penilaian mudah dilakukan dan murah.

Pendapat lainnya dikemukakan

Cece Rahmat \& Suherdi (1999:32-34) bahwa prinsip yang penting dalam melakukan penilaian adalah prinsip keterpaduan, prinsip kelengkapan, prinsip kesinambungan, prinsip objektifitas, prinsip relevansi, prinsip keteraturan. Keterpaduan artinya kegiatan penilaian tidak boleh terlepas dari kegiatan pengajaran. Dalam penilaian, harus diperhatikan tujuan-tujuan instruksional atau ruang lingkup bahan ajar yang dipelajari siswa. Prinsip kelengkapan bermakna bahwa penilaian perlu dilakukan secara menyeluruh sesuai dengan tujuan penilaian dan ruang lingkup bahan ajar yang ingin diungkap maupun teknik serta instrumen yang digunakan. Prinsip kesinambungan artinya program penilaian hendaknya dilakukan seiring dengan rangkaian kegiatan proses belajar mengajar. Prinsip objektifitas bermakna bahwa hasil penilaian harus menggambarkan keadaan sebenarnya, sesuai dengan kemampuan objektif siswa. Prinsip relevansi mengandung maksud bahwa pengambilan keputusan penilaian hendaknya berdasarkan data yang relevan atau data yang dibutuhkan sesuai dengan tujuan penilaian. Prinsip keteraturan artinya dalam melaksanakan evaluasi perlu memperhatikan prosedur dan langkahlangkah yang perlu diikuti, sehingga hasil penilaian dapat dipertanggungjawabkan.

Ada beberapa jenis atau pola alat penilaian yang dapat digunakan dalam kegiatan evaluasi hasil belajar siswa yaitu sebagai berikut :

\section{a. Tes Uraian}

Tes uraian adalah pertanyaan yang menuntut siswa untuk mengorganisasikan dan menyatakan jawabannya menurut katakata/kalimatnya sendiri (Nana Sudjana, 2004:35). Jawaban tersebut dapat berbentuk mengingat kembali, menyusun atau memadukan pengetahuan yang telah dipelajari ke dalam rangkaian kalimat atau pernyataan yang tersusun dengan baik. Menurut Djemari Mardapi (2004: 90) tes uraian dibedakan menjadi uraian objektif dan non objektif. Bentuk uraian objektif sering digunakan pada mata pelajaran yang batasannya jelas, misalnya mata pelajaran statistik, matematika dan sebagainya. Soal pada tes ini jawabannya hanya satu, mulai dari memilih rumus 
yang tepat, memasukkan angka dalam rumus, menghitung hasil dan menafsirkan hasilnya. Pada tes bentuk uraian objektif ini, sistem penskoran dapat dibuat dengan jelas dan rinci. Bentuk tes uraian non objektif menuntut kemampuan siswa untuk menyampaikan, memilih, menyusun, dan memadukan ide yang telah dimilikinya dengan menggunakan kata-katanya sendiri. Bentuk tes ini tepat untuk tipe soal penerapan, analisis, sistesis dan evaluasi.

\section{Langkah awal dalam} mengembangkan tes uraian adalah menetapkan spesifikasi tes. Spesifikasi tes berisi tentang uraian yang menunjukkan keseluruhan kualitas dan ciri-ciri yang harus dimiliki dan yang akan dikembangkan (Sumadi Suryabrata, 2004:68). Spesifikasi tes tidak saja merupakan pegangan yang akan mengarahkan dan membimbing kerja penulis akan tetapi berfungsi pula sebagai bagian dari informasi bagi siswa mengenai apa yang akan mereka hadapi dalam tes dan apa yang harus mereka persiapkan sebaik-baiknya. Djemari Mardapi (2004:88) menyatakan bahwa langkah-langkah dalam penyusunan spesifikasi tes yaitu : (1) menentukan tujuan tes, (2) menyusun kisi - kisi tes, (3) memilih bentuk tes dan (4) menentukan panjang tes.

Penyusunan tes harus memperhatikan tujuan yang ingin dicapai yaitu sesuai kompetensi dasar yang telah ditetapkan dalam silabus mata pelajaran dan dijabarkan oleh guru dalam bentuk kisi-kisi tes. Lebih lanjut Djemari Mardapi (2004:89) menyatakan bahwa kisi-kisi merupakan tabel matrik yang berisi spesifikasi soal-soal yang akan dibuat. Kisi-kisi merupakan acuan bagi penulis soal, sehingga siapapun yang menulis soal akan menghasilkan soal yang isi dan tingkat kesulitannya relatif sama.

Beberapa keunggulan dari tes uraian yaitu karena :

1) Menekankan kepada pengukuran kemampuan dan ketrampilan mengintegrasikan berbagai buah pikiran dan sumber informasi kedalam suatu pola berpikir tertentu, yang disertai ketrampilan memecahkan masalah.

2) Meningkatkan motivasi siswa untuk menguasai bahan secara penuh. Hal ini didasarkan pada alasan bahwa siswa akan mengungkapkan 
jawabannya dengan kata-kata sendiri sehingga dituntut benar-benar mamahami keseluruhan materi beserta hubungan antara konsep-konsep yang ada.

3) Secara umum keunggulan tes bentuk uraian menurut Sumarna Surapranata (2004:232) adalah dapat mengukur kemampuan siswa dalam hal mengorganisasikan pikirannya, mengemukakan pendapatnya dan mengekspresikan gagasan-gagasan dengan menggunakan kata-kata atau kalimat siswa sendiri. Tes ini dapat digunakan untuk mengukur kemampuan berpikir kritis ataupun problem solving yang sangat sukar diukur melalui soal pilihan ganda.

Anas Sudijono (2005:102-104) menyatakan bahwa tes uraian memiliki keunggulan dan kelemahan. Keunggulan bentuk tes uraian : (1) Pembuatan tes dapat dilakukan dengan mudah dan cepat. Hal ini disebabkan karena kalimatkalimat tes pada tes uraian relatif pendek sehingga penyusunannya tidak terlalu sulit dari segi waktu, tenaga, pikiran, peralatan dan biaya. (2) Penggunaan tes uraian dapat mengurangi kemungkinan terjadinya spekulasi dari peserta tes dalam menjawab tes. (3) Melalui tes uraian dapat diketahui seberapa jauh tingkat penguasaan peserta tes dalam memahami materi yang dinyatakan dalam tes tersebut. (4) Dengan tes uraian peserta tes akan terdorong dan terbiasa untuk mengungkapkan pendapatnya dengan menggunakan susunan kalimat sesuai dengan gaya bahasanya sendiri. Lebih lanjut Sudijono mengemukakan bahwa tes uraian juga memiliki beberapa kelemahan, yaitu : (1) pada tes uraian kurang dapat menampung atau mencakup isi dari materi pembelajaran yang luas, (2) cara menyeleksi tes uraian cukup sulit baik dari segi waktu, tenaga dan pikiran, (3) dalam penentuan skor tester cenderung subjektif dalam memberikan skor pada siswa, (4) pengkoreksian lembar jawaban tes uraian sulit untuk diserahkan pada orang lain sebab orang yang memeriksa tes harus mengetahui jawaban yang sempurna, dan (5) daya ketepatan (validitas) dan daya keajegan mengukur (reliabilitas) tes uraian tergolong rendah.

Dengan mempertimbangkan dari berbagai segi keunggulan dan kelemahan bentuk tes di atas, maka seorang evaluator 
harus dapat menentukan jenis tes yang tepat sesuai aspek tujuan evaluasi yang ingin diukur dan waktu yang tersedia pada penyusunan tes itu sendiri. Sehingga hasil evaluasi belajar yang dilaksanakan menghasilkan informasi yang akurat, dapat berguna sebagai bahan pertimbangan dalam mengambil keputusan.

\section{b. Penskoran Tes Uraian}

Pedoman penskoran berisi kemungkinan-kemungkinan jawaban benar yang berupa kata-kata kunci peserta besarnya skor yang diberikan. Pedoman ini disusun untuk mengurangi faktor subjektifitas pada saat pemeriksaan (koreksi jawaban siswa).

Beberapa pedoman yang dapat dijadikan bahan pertimbangan dalam melakukan penskoran terhadap tes uraian adalah sebagai berikut :

1) Buatlah terlebih dahulu semacam pedoman pemberian skor yang berisi garis besar atau pokok-pokok jawaban yang dikehendaki.

2) Apabila jawaban yang dikehendaki dapat dibatasi secara pokok, maka pedoman yang diperlukan akan berupa kriteria-kriteria jawaban yang dianggap benar. Apabila jawaban yang dikehendaki berupa uraian panjang yang dapat dianggap benar dari berbagai versi jawaban, maka pedoman yang diperlukan akan berupa model jawaban yang dianggap benar.

3) Sebelum melakukan pemeriksaan jawaban sebaiknya diusahakan agar kita tidak mengetahui identitas pemilik kertas jawaban. Hal ini dimaksud untuk menghindari efek emosional yang bersipat subjektif yang kita rasakan terhadap penjawab.

4) Periksalah jawaban terhadap item pertama dari seluruh siswa, baru kemudian memeriksa item nomor berikutnya.

5) Jangan melakukan pemeriksaan jawaban dan pemberian skor sewaktu berada dalam keadaan yang tidak tenang, terlalau gembira atau sedang lelah. Keadaan emosi disaat melakukan pemberian skor terhadap tipe uraian sangat mempengaruhi objektifitas pemberi skor (Saifuddin Azwar, 2005:118-119).

\section{c. Tes Objektif}

Tes bentuk objektif adalah suatu tes yang jawabannya terdiri atas pertanyaan atau pernyataan yang sifatnya belum selesai, dan untuk menyelesaikannya harus dipilih salah satu atau lebih dari kemungkinan jawaban yang telah disediakan pada tiap-tiap butir tes yang bersangkutan (Anas Sudijono, 2005:118) 
Sumarna Surapranata (2004:178) menyatakan bahwa tes pilihan ganda mempunyai keunggulan dan kelemahan. Keunggulan tes berbentuk pilihan ganda

(1) jumlah materi yang dapat ditanyakan relatif tidak terbatas dibandingkan dengan materi yang dapat dicakup oleh materi yang dapat dicakup oleh tes model lainnya. Jumah tes yang dinyatakan relatif banyak, (2) dapat mengukur berbagai jenjang kognitif mulai dari ingatan sampai ke evaluasi, (3) penskorannya mudah, cepat, objektif, dan dapat mencakup ruang lingkup materi yang luas dalam satu tes untuk suatu kelas atau jenjang, (4) sangat tepat untuk ujian yang pesertanya sangat banyak, sedangkan hasilnya harus segera seperti ujian akhir nasional, dan (5) reliabilitas tes pilihan ganda lebih tinggi dibandingkan dengan tes uraian.

\section{Sumarna Surapranata}

(2004:178) juga mengemukakan beberapa kelemahan tes pilihan ganda, sebagai berikut :

(1) kurang dapat digunakan untuk mengukur kemampuan verbal, (2) siswa tidak mempunyai keleluasaan dalam menulis, mengorganisasikan, dan mengekspresikan gagasan yang mereka miliki yang dituangkan dalam bentuk kata atau kalimatnya sendiri, (3) tidak digunakan untuk mengukur kemampuan problem solving, (4) sangat sensitif dengan menerka. Tes yang mempunyai empat distraktor jawaban, peserta tes memiliki kemungkinan menerka
$25 \%$ dan untuk tes yang distraktornya 5 jawaban peserta memiliki kemungkinan menerka sebesar 20\%, (5) penyusunan tes yang baik membutuhkan waktu yang relatif lama dibandingkan dengan bentuk tes lain, dan (6) sangat sukar menentukan alternatif jawaban yang benar-benar homogen, logis dan berfungsi.

Djemari Mardapi (2004:75) menyatakan bahwa pedoman utama dalam pembuatan butir tes bentuk pilihan ganda harus memperhatikan beberapa hal sebagai berikut :

1) Pokok soal harus jelas.

2) Pilihan jawaban homogen dalam arti isi.

3) Panjang kalimat pilihan jawaban relatif sama.

4) Tidak ada petunjuk jawaban benar.

5) Hindari menggunakan pilihan jawaban semua benar atau semua salah.

6) Pilihan jawaban angka diurutkan.

7) Semua pilihan jawaban logis.

8) Jangan menggunakan negatif ganda.

9) Kalimat yang digunakan sesuai dengan tingkat perkembangan peserta didik.

10) Bahasa Indonesia yang digunakan baku.

11) Letak pilihan jawaban benar ditentukan secara acak. 


\subsection{Kualitas Butir Tes}

Kualitas butir tes dapat diketahui melalui analisis butir tes. Analisis tes dimaksudkan untuk mengetahui karakteristik butir tes. Analisis dapat dilakukan sebelum dan sesudah butir tes dipergunakan. Analisis butir tes sebelum dipergunakan dilakukan dengan cara menelaah butir tes secara kualitatif berdasarkan materi, konstruksi, dan bahasa. Analisis butir tes sesudah tes tersebut digunakan dengan cara menganalisis data empiris, dalam penelitian ini butir tes uraian analisis dilakukan dengan menggunakan cara manual, yaitu dengan membuat tabel perhitungan setiap butir tes sebagai alat bantu. Tabel perhitungan dibuat setelah diketahui jumlah skor hasil ulangan harian siswa, lalu siswa dibagi menjadi dua kelompok, yakni 27\% kelompok atas (skor tinggi) dan 27\% kelompok bawah (skor rendah) (Fernandes, 1985:98). Proses selanjutnya nilai hasil analisis yang diperoleh dimasukan ke dalam kriteria untuk mengetahui dua macam karakteristik butir tes, yaitu tingkat kesukaran dan daya beda butir tes.

Tes yang baik dapat memberikan hasil ukur yang cermat dan akurat, sehingga hasil tes mampu menunjukkan perbedaan-perbedaan kecil yang ada pada objek ukurnya. Untuk mendapatkan tes yang baik maka perlu dilakukan analisis terhadap butir tes. Analisis butir tes adalah pengkajian pertanyaan-pertanyaan tes agar diperoleh perangkat pertanyaan yang memiliki kualitas yang memadai (Nana Sudjana, 2004:135). Menurut Masters \& Keeves (Barnard, 1999:197) tujuan utama analisis butir tes, yaitu untuk memperoleh informasi objektif tentang butir tes yang digunakan dan untuk mengidentifikasi butir-butir yang kurang baik. Butir-butir tes tersebut mungkin terlalu mudah, sukar, atau tidak dapat membedakan antara siswa yang berkemampuan tinggi dan rendah. Secara garis besar ada dua cara menganalisis butir tes, yaitu analisis butir soal secara teoritik/kualitatif dan analisis butir tes secara empiris/kuantitatif.

Analisis secara kualitatif merupakan penelaahan butir tes yang ditinjau dari segi materi, konstruk, dan bahasa (Sumarna Surapranata, 2004:2). Analisis materi dimaksudkan sebagai penelaahan yang berkaitan dengan keilmuan yang ditanyakan dalam soal serta tingkat kemampuan yang sesuai 
dengan soal. Analisis konstruksi dimaksudkan sebagai penelaahan yang umumnya berkaitan dengan teknik penulisan soal. Analisis bahasa dimaksudkan sebagai penelaahan soal yang berkaitan dengan penggunaan bahasa Indonesia yang baik dan benar menurut EYD.

\section{PENUTUP}

Pemilihan bentuk pendekatan analisis hasil evaluasi belajar siswa yang digunakan sangat tergantung kepada penggunaan dan tujuan pengukuran yang ingin dicapai. Karena setiap model analisis baik teori tes klasik maupun teori respons butir memiliki persyaratan tertentu serta kecocokan dalam penggunaannya. Teknik evaluasi harus dipilih sesuai dengan tujuan yang akan dilayaninya dan harus dipertimbangkan apakah teknik evalusi merupakan metode yang paling efektif untuk menetukan apa yang ingin diketahui oleh siswa.

\section{Evaluasi yang komprehensif} menuntut berbagai teknik evaluasi. Salah satu alasan perlunya berbagai prosedur evaluasi adalah karena setiap jenis hanya menyajikan bukti - bukti yang unik tetapi terbatas tentang perilaku siswa. Untuk mendapatkan gambaran yang komplit tentang pencapaian siswa perlu kombinasi hasil dari berbagai teknik. Karena itu pemakaian teknik pendekatan evaluasi yang sewajarnya menuntut kewaspadaan akan keterbatasannya seperti juga kekuatannya. Semua alat evaluasi selalu mengandung kekurangan tertentu. Kesadaran atas keterbatasan alat evaluasi memungkinkan dapat memakainya lebih efektif, dan kesalahan - kesalahan dalam teknik evaluasi dapat dihilangkan dengan cara hati-hati dalam memilih dan memakainya. Salah satu alat evaluasi yang dapat digunakan untuk mengukur hasil belajar siswa menggunakan tes. Tes yang baik dapat memberikan hasil ukur yang cermat dan akurat, sehingga hasil tes mampu menunjukkan perbedaan - perbedaan kecil yang ada pada objek ukurnya. Untuk mendapatkan tes yang baik maka perlu dilakukan analisis terhadap butir tes. Tujuan utama analisis butir tes, yaitu untuk memperoleh informasi objektif tentang butir tes yang digunakan serta untuk mengidentifikasi butir-butir yang kurang baik. Butir-butir tes tersebut mungkin terlalu mudah, sukar, atau tidak 
dapat membedakan antara siswa yang berkemampuan tinggi dan rendah. Secara garis besar ada dua cara menganalisis butir tes, yaitu analisis butir soal secara teoritik/kualitatif dan analisis butir tes secara empiris/kuantitatif.

Analisis secara kualitatif merupakan penelaahan butir tes yang ditinjau dari segi materi, konstruk, dan bahasa. Analisis materi dimaksudkan sebagai penelaahan yang berkaitan dengan keilmuan yang ditanyakan dalam soal serta tingkat kemampuan yang sesuai dengan soal. Analisis konstruksi dimaksudkan sebagai penelaahan yang umumnya berkaitan dengan teknik penulisan soal. Analisis bahasa dimaksudkan sebagai penelaahan soal yang berkaitan dengan penggunaan bahasa Indonesia yang baik dan benar menurut EYD, sedangkan analisis kuantitatif menurut pendekatan teori tes klasik menghasilkan karakteristik butir yang meliputi tingkat kesukaran (p), daya pembeda (d), dan efektivitas distraktor. Selain itu, dengan analisis pendekatan teori klasik juga dapat diketahui reliabilitas, dan kesalahan baku pengukuran. Untuk melihat tingkat kesukaran, daya pembeda dan efektifitas distraktor dilakukan analisis setiap butir tes, sedangkan reliabilitas dan kesalahan baku pengukuran dapat dilihat dengan cara menganalisis butir tes secara keseluruhan.

Dengan demikian untuk menilai kualitas butir tes banyak faktor yang harus diperhatikan mulai dari tingkat kesukaran butir, daya beda dan fungsi pilihan jawaban, terutama distraktornya yaitu harus tampak sebagai jawaban yang benar bagi peserta tes dari kelompok yang berkemampuan rendah. Tetapi harus tampak sebagai jawaban yang salah bagi peserta tes dari kelompok yang berkemampuan tinggi. Sekalipun suatu butir tes terlalu sukar atau terlalu mudah, namun apabila (1) daya pembeda butir tes, dan (2) distribusi jawaban memenuhi kriteria maka butir tes tersebut masih dapat diterima sebagai butir tes yang cukup baik. Kriteria yang dimaksud adalah indeks daya pembeda butir tes menggunakan korelasi biserial atau point biserial $\geq 0,3$ dan indeks daya pembeda pilihan jawaban negatif kecuali kunci jawaban.

\section{DAFTAR PUSTAKA}

Ahmann, J.S., \& Glock, M. 1981. Evaluating Student Progress : Principles of Test and 
Measurement. Boston : Allyn and Bacon.

Allen, J. M., \& Yen, M.W. 1979. Introduction to Measurement Theory. Monterey : Brooks/Cole Publishing Company.

Anas Sudijono. 2005. Pengantar Evaluasi pendidikan. Jakarta : Raja Grafindo Persada.

Bahrul Hayat. 1997. Manual Iteman and Test Analysis (ITEMAN). Jakarta : Pusat Penelitian dan Pengembangan Sistem pengujian Balitbang, Depdikbud.

Cece Rakhmat., \& Didi Suherdi. 1999. Evaluasi Pengajaran. Jakarta : Dirjen Dikti, Depdikbud.

Dali S, Naga. 1992. Pengantar Teori Sekor pada Pengukuran Pendidikan. Jakarta : Gunadarma.

Djemari Mardapi., dkk. 1999. Survei Kegiatan Guru dalam Melakukan Penilaian di Kelas. Laporan Penelitian. Yogyakarta : Pusbangsisjian Lemlit IKIP Yogyakarta dan Pusisjian Balitbang, Depdikbud.

- 2003. Konstruksi Tes dan Analisis Butir. Makalah pada seminar Lokakarya Metodologi Interaksi Pembelajaran Universitas Muhammadiyah Surakarta, Surakarta. . 2004. Penyusunan Tes Hasil Belajar. Bahan Kuliah, Yogyakarta : Program Pasca Sarjana UNY. . 2005. Pedoman Umum Pengembangan Penilaian. Yogyakarta : Tim Pasca Sarjana UNY.

Ebel, R.L., \& Frisbie, D.A. 1986. Essentials of Educational
Measurement. New Jersey : Englewod Cliffs Prentice Hall, Inc

Fernandes, H.J.X. 1980. Testing and Measurement. Jakarta : National Education Planning, Evaluating and Curriculum Development. . 1985. Measurement Scales. Jakarta : National Education Planning, Evaluating and Curriculum Development.

Gronlund, N.E., \& Linn, R.L. 1990. Measurement and Evaluation in Teaching $\left(6^{\text {th }} e d\right)$. New York : Mcmillan Publishing Co.Inc.

Hambleton, R.K., \& Swaminathan, H. 1991. Item Response Theory: Principles and Applications. Boston : Kluwer-Nijhoff Publishing.

Masters, G.N., \& Keeves, J.P. 1999. Item Analysis in Test Construction. dalam Barnard, J.J. (Ed). Advances in Measurement in Educational Research and Assessment. New York : Elsevier Science, Ltd.

Nana Sudjana. 2004. Penilaian Hasil ProsesB Mengajar. Bandung : Remaja Rosdakarya .

Saifuddin Azwar. 2005. Tes Prestasi : Fungsi dan Pengembangan Pengukuran Prestasi Belajar. ( $2^{\text {nd }}$ ed.). Yogyakarta : Pustaka Pelajar.

Suharsimi Arikunto. 2006. Dasar-dasar Evaluasi Pendidikan (Edisi Revisi). Jakarta : Bumi Aksara.

Sumadi Suryabrata. 2004. Pengembangan Alat Ukur Psikologis. Yogyakarta : Andi Offset.

Sumarna Surapranata. 2004. Panduan Penulisan Tes Tertulis 
Implementasi Kurikulum 2004. Bandung : Rosda Karya.

. 2004. Analisis, Validitas, Reliabilitas dan Interpretasi Hasil Tes Implementasi Kurikulum 2004. Bandung : Rosda Karya.

Worthen, B.R., \& Sanders, J.R. 1973. Educational Evaluation : Theory and Practice. Worthington, Ohio : Publishing Company. 